\title{
Pollen-based paleoenvironmental and paleoclimatic change at Lake Ohrid (south-eastern Europe) during the past 500 ka
}

\author{
Laura Sadori $^{1}$, Andreas Koutsodendris ${ }^{2}$, Konstantinos Panagiotopoulos ${ }^{3}$, Alessia Masi ${ }^{1}$, Adele Bertini ${ }^{4}$, \\ Nathalie Combourieu-Nebout ${ }^{5}$, Alexander Francke ${ }^{6}$, Katerina Kouli ${ }^{7}$, Sébastien Joannin ${ }^{8}$, Anna Maria Mercuri ${ }^{9}$, \\ Odile Peyron $^{8}$, Paola Torri ${ }^{9}$, Bernd Wagner ${ }^{6}$, Giovanni Zanchetta ${ }^{10}$, Gaia Sinopoli ${ }^{1}$, and Timme H. Donders ${ }^{11}$ \\ ${ }^{1}$ Dipartimento di Biologia Ambientale, Università di Roma "La Sapienza", Rome, Italy \\ ${ }^{2}$ Paleoenvironmental Dynamics Group, Institute of Earth Sciences, Heidelberg University, Heidelberg, Germany \\ ${ }^{3}$ Institute of Geography and Education, University of Cologne, Cologne, Germany \\ ${ }^{4}$ Dipartimento di Scienze della Terra, Università di Firenze, Florence, Italy \\ ${ }^{5}$ HNHP - Histoire naturelle de l'Homme préhistorique, UMR 7194 CNRS, Département de Préhistoire, Muséum national \\ d'Histoire naturelle, Institut de Paléontologie Humaine, Paris, France \\ ${ }^{6}$ Institute for Geology and Mineralogy, University of Cologne, Cologne, Germany \\ ${ }^{7}$ Faculty of Geology and Geoenvironment, National and Kapodistrian University of Athens, Athens, Greece \\ ${ }^{8}$ CNRS UMR 5554, Institut des Sciences de l'Evolution de Montpellier, Université de Montpellier, Montpellier, France \\ ${ }^{9}$ Dipartimento di Scienze della Vita, Laboratorio di Palinologia e Paleobotanica, Università di Modena e Reggio Emilia, \\ Modena, Italy \\ ${ }^{10}$ Dipartimento di Scienze della Terra, University of Pisa, Pisa, Italy \\ ${ }^{11}$ Palaeoecology, Department of Physical Geography, Utrecht University, Utrecht, the Netherlands
}

Correspondence to: Alessia Masi (alessia.masi@uniroma1.it)

Received: 31 August 2015 - Published in Biogeosciences Discuss.: 17 September 2015

Revised: 20 December 2015 - Accepted: 8 February 2016 - Published: 8 March 2016

\begin{abstract}
Lake Ohrid is located at the border between FYROM (Former Yugoslavian Republic of Macedonia) and Albania and formed during the latest phases of Alpine orogenesis. It is the deepest, the largest and the oldest tectonic lake in Europe. To better understand the paleoclimatic and paleoenvironmental evolution of Lake Ohrid, deep drilling was carried out in 2013 within the framework of the Scientific Collaboration on Past Speciation Conditions (SCOP$\mathrm{SCO}$ ) project that was funded by the International Continental Scientific Drilling Program (ICDP). Preliminary results indicate that lacustrine sedimentation of Lake Ohrid started between 1.2 and $1.9 \mathrm{Ma}$ ago. Here we present new pollen data (selected percentage and concentration taxa/groups) of the uppermost $\sim 200 \mathrm{~m}$ of the $569 \mathrm{~m}$ long DEEP core drilled in the depocentre of Lake Ohrid. The study is the fruit of a cooperative work carried out in several European palynological laboratories. The age model of this part of the core is based on 10 tephra layers and on tuning of biogeochemical proxy data to orbital parameters.
\end{abstract}

According to the age model, the studied sequence covers the last $\sim 500000$ years at a millennial-scale resolution $(\sim 1.6 \mathrm{ka})$ and records the major vegetation and climate changes that occurred during the last 12 (13 only pro parte) marine isotope stages (MIS). Our results indicate that there is a general good correspondence between forested/nonforested periods and glacial-interglacial cycles of the marine isotope stratigraphy. The record shows a progressive change from cooler and wetter to warmer and drier interglacial conditions. This shift in temperature and moisture availability is visible also in vegetation during glacial periods.

The period corresponding to MIS11 (pollen assemblage zone OD-10, 428-368 ka BP) is dominated by montane trees such as conifers. Mesophilous elements such as deciduous and semi-deciduous oaks dominate forest periods of MIS5 (PASZ OD-3, 129-70 ka BP) and MIS1 (PASZ OD1, 14 ka BP to present). Moreover, MIS7 (PASZ OD-6, 245$190 \mathrm{ka}$ ) shows a very high interglacial variability, with alternating expansions of montane and mesophilous arboreal 
taxa. Grasslands (open vegetation formations requiring relatively humid conditions) characterize the earlier glacial phases of MIS12 (PASZ OD-12, 488-459 ka), MIS10 (corresponding to the central part of PASZ OD-10, 428-366 ka) and MIS8 (PASZ OD-7, 288-245 ka). Steppes (open vegetation formations typical of dry environments) prevail during MIS6 (OD-5 and OD-4, 190-129 ka) and during MIS4-2 (PASZ OD-2, 70-14 ka).

Our palynological results support the notion that Lake Ohrid has been a refugium area for both temperate and montane trees during glacials. Closer comparisons with other long southern European and Near Eastern pollen records will be achieved through ongoing high-resolution studies.

\section{Introduction}

The study of past climate change is pivotal to better understand current climate change (Tzedakis et al., 2009) and its impact on terrestrial ecosystems, particularly at the midlatitudes, where human activities are concentrated. It is well established that the study of fossil pollen contained in sediments fundamentally contributes to the reconstruction of terrestrial palaeoenvironmental changes that occurred during the Quaternary, and constitutes the only quantitative proxy that can provide continuous and accurate representations of vegetation changes. This fact was already clear at the end of the 1960s when the pioneer pollen study of Wijmstra (1969) at Tenaghi Philippon (Greece) was published. The study of long lacustrine pollen records from southern Europe is particularly important, as at such latitudes, glaciations have not caused stratigraphic gaps in lacustrine systems, unlike northern European sequences (e.g. Zagwijn, 1992). The relationship of terrestrial vegetation with terrestrial, marine and ice core records is a further step in the understanding of global climate dynamics and lead-lag relations. A broader correspondence between the climate signals provided by terrestrial pollen records and marine oxygen isotope records has been observed (e.g. Tzedakis et al., 1997, 2001). Subsequent studies of both terrestrial (pollen) and marine (planktonic and benthic oxygen isotopes) proxies in marine cores from the Iberian margin confirmed the mostly in-phase relation of Mediterranean and North Atlantic climate variability during the Late Pleistocene (e.g. Sánchez Goñi et al., 1999; Tzedakis et al., 2004b). But the exact phase relations to marine systems, regional variations in vegetation response, and exact locations of refugia are still poorly known mostly due to the complications of obtaining records in key regions and with independent age control.

Southern Europe encompasses five lacustrine pollen records spanning more than the last two glacial-interglacial cycles. They are the composite record of Bouchet/Praclaux in southern France, spanning the last $\sim 450 \mathrm{ka}$ (Reille et al., 2000), Valle di Castiglione in central Italy, spanning the last $\sim 300 \mathrm{ka}$ (Follieri et al., 1988, 1989), Ioannina in western Greece, spanning the last $\sim 480 \mathrm{ka}$ (Tzedakis, 1994b), Kopais, in south-eastern Greece, spanning the last $\sim 500 \mathrm{ka}$ (Okuda et al., 2001), and Tenaghi Philippon, the $\sim 1.35$ million-year old European lacustrine record from north-eastern Greece (Tzedakis et al., 2006; Pross et al., 2015). In the Near East, long continental sedimentary sequences have been studied in Lake Van (eastern Turkey) spanning the last $\sim 600 \mathrm{ka}$ (Litt et al., 2014), in Lake Urmia (north-western Iran) spanning $200 \mathrm{ka}$ (Djamali et al., 2008) and in lake Yamounneh (Lebanon) spanning the last $\sim 400 \mathrm{ka}$ (Gasse et al., 2015). However, these sediment cores have not been studied with high temporal resolution, which is a precondition for a deeper understanding of the palaeoenvironmental and palaeoclimatic evolution of terrestrial ecosystems (Brauer et al., 2007; Magny et al., 2013; Moreno et al., 2015).

Southern European long pollen records have caught the attention of many researchers, as these archives are arguably among the best available sources of information for past vegetation and climate changes (e.g. Tzedakis et al., 1997, 2001; Pross et al., 2015). Molecular genetic data revealed considerable divergence between populations of many arboreal species in southern refugial centres in Iberia, Italy, the Balkans and Greece. Arboreal refugia and migration paths, identified by both biogeographical, palaeobotanical and phylogeographical studies (Petit et al., 2005; Cheddadi et al., 2006; Magri et al., 2006; Liepelt et al., 2009; Médail and Diadema, 2009; Tzedakis, 2009; Tzedakis et al., 2013), sometimes confirmed the speculated locations (e.g. Bennett et al., 1991) and their link to modern biodiversity hotspots, but most mechanisms still have to be fully understood. From this perspective it is essential to compare the locations of refugia and those of regional hotspots of plant biodiversity.

Located in a strategic position between higher-latitude and lower-latitude climate systems, Lake Ohrid is at the border between the Former Yugoslavian Republic of Macedonia (FYROM) and Albania. As one of the biosphere reserves of the United Nations Educational, Scientific, and Cultural Organization (UNESCO), it is a transboundary World Heritage Site in the Balkans. It is thought to be the oldest extant lake in Europe, with an uninterrupted lacustrine sedimentation probably starting between 1.2 and $1.9 \mathrm{Ma}$ (Wagner et al., 2014; Lindhorst et al., 2015). The sensitive ecosystem response of the Dessarete lakes Ohrid and Prespa to climate variability during the last glacial-interglacial cycle has been documented in several studies dealing with terrestrial vegetation composition and land cover (Lézine et al., 2010; Wagner et al., 2009, 2010; Panagiotopoulos, 2013; Panagiotopoulos et al., 2013, 2014), with macrophytes and phytoplankton communities (Panagiotopoulos et al., 2014; Cvetkoska et al., 2015a, b), and with stable isotope studies (Leng et al., 2010). These findings illustrate the value of the "sister" lakes Ohrid and Prespa as environmental archives. Combined with the lakes' high biological endemism (Albrecht and Wilke, 2008; Föller et al., 2015) and the potential for in- 
dependent age control through numerous volcanic ash layers (Sulpizio et al., 2010; Leicher et al., 2015), the Lake Ohrid record is a prime target to study past and present biodiversity and evolution.

The SCOPSCO (Scientific Collaboration on Past Speciation Conditions in Lake Ohrid) international science team carried out a deep drilling campaign in spring 2013 in the framework of the International Continental Scientific Drilling Program (ICDP). The aim of this initiative is an interdisciplinary analysis of environmental and climate variability under different boundary conditions throughout the Pleistocene. Initial results, based on the DEEP borehole in the lake centre, show approximately $1.2 \mathrm{Ma}$ of continuous lake sedimentation, with clear glacial-interglacial signatures represented in the sediment properties (Wagner et al., 2014). Here we report new palynological data from the upper $\sim 200 \mathrm{~m}$ of the DEEP core from Lake Ohrid, representing vegetation dynamics over the past $\sim 500 \mathrm{ka}$.

Specific objectives of this study are (1) to outline the flora and vegetation changes that occurred in the last half million years in the area surrounding Lake Ohrid, (2) to understand the glacial and interglacial vegetation dynamics, and (3) to correlate the vegetation changes with benthic and planktic marine isotope stratigraphy.

Considering the core length, in this paper we aim to provide a comprehensive overview of millennial-scale vegetation dynamics during glacial-interglacial stages at Lake Ohrid before analysing intervals at high resolution. The aim of this study is not in fact to discuss in detail the features of either interglacial or glacial periods. Existing highresolution pollen studies focusing on different time intervals (e.g. Tzedakis et al., 2004b, 2009; Tzedakis, 2007; Fletcher et al., 2010; Margari et al., 2010; Moreno et al., 2015) offer a more detailed picture of ecosystem dynamics in the Mediterranean region. High-resolution studies using the exceptional Lake Orhid archive are in progress for selected intervals (e.g. MIS 5-6, MIS 11-12 and MIS 35-42).

\section{Site setting}

Lake Ohrid $\left(40^{\circ} 54^{\prime}\right.$ to $41^{\circ} 10^{\prime} \mathrm{N}, 20^{\circ} 38^{\prime}$ to $\left.20^{\circ} 48^{\prime} \mathrm{E}\right)$ is a transboundary lake located in the Balkan Peninsula within the Dinaride-Albanide-Hellenide mountain belt, at the border between Albania and FYROM (Fig. 1). It is the deepest and largest tectonic lake in Europe. It is located in a deep tectonic graben, with still tectonically active faults running parallel to the N-S orientation of the lake (e.g. Hoffmann et al., 2012).

Lake Ohrid has a sub-elliptical shape: it is $30.3 \mathrm{~km}$ long and $15.6 \mathrm{~km}$ wide and is located at an altitude of $693 \mathrm{~m}$ a.s.1. It has a water surface of $\sim 360 \mathrm{~km}^{2}$, a maximum water depth of $293 \mathrm{~m}$ (Lindhorst et al., 2015) and a watershed area of $\sim 1400 \mathrm{~km}^{2}$. The lake is surrounded by the Mokra mountains to the west (maximum altitude $1514 \mathrm{~m}$ ) and the Gali-

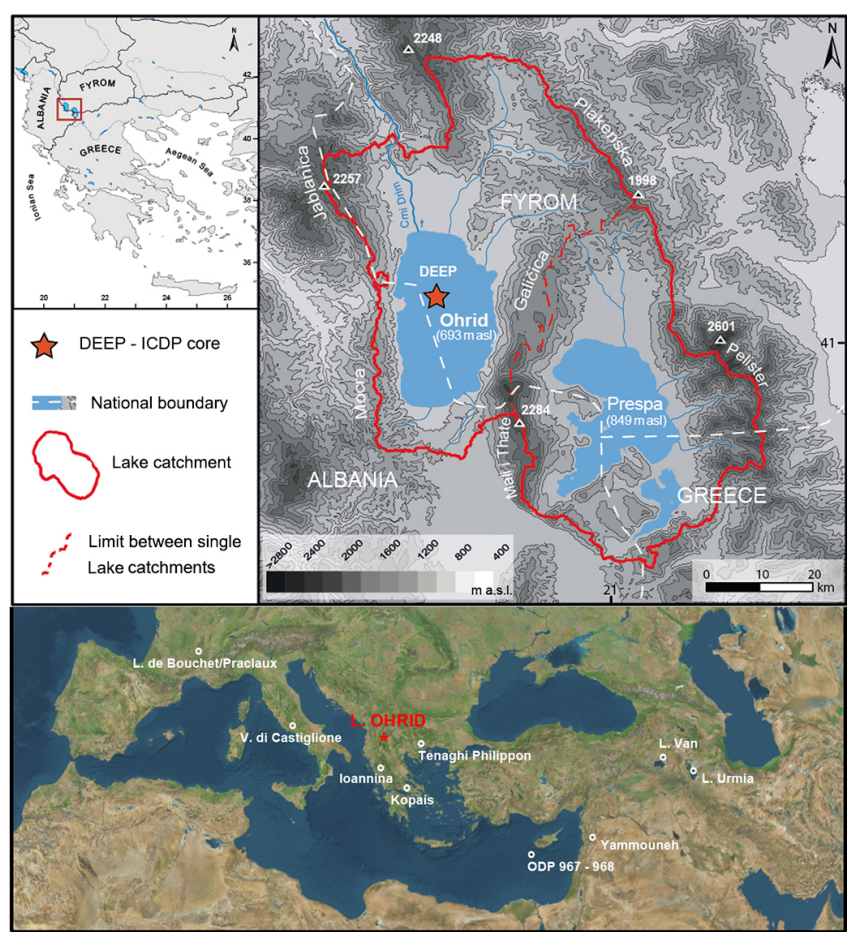

Figure 1. Map of Lake Ohrid modified from Panagiotopoulos (2013) and locations of terrestrial and marine records discussed in the text.

čica mountains to the east (maximum altitude $2265 \mathrm{~m}$ ). The water body of the lake is fed $50 \%$ by sub-lacustrine karstic flow and $50 \%$ by surface inflow; river runoff is at present $\sim 20 \%$ of the total inflow and was even lower prior to 1962 , when the Sateska River was diverted into the northern part of Lake Ohrid. Major fluvial inflows are from the rivers Daljan, Sateska, Cerava and Voljorek.

The river Crni Drim is the lake emissary and its outflow is artificially controlled. Lake Ohrid is separated from Lake Prespa, which is situated at $849 \mathrm{~m}$ a.s.l. ( $\sim 150 \mathrm{~m}$ higher $)$, by the Galičica mountain range (Fig. 1). The two lakes are hydrologically connected through underground karst channels. Diatom palaeoecology shows that, despite the hydrological connectivity, the lake ecosystems respond independently to external forcing (Cvetkoska et al., 2015b). Because of the large extent of the karst system and the hydrological connection with Lake Prespa, the exact spatial distribution of the Lake Ohrid drainage basin is hard to determine (Watzin et al., 2002; Popovska and Bonacci, 2007; Wagner et al., 2009). If Lake Prespa and its tributaries are included in the catchment of Lake Ohrid, its area is calculated to $3921 \mathrm{~km}^{2}$ (Portal Unesco, http://opendata.unesco. org/project/41304-549RER4000/).

The bedrock around the lake mainly consists of low- to medium-grade metamorphosed Paleozoic sedimentary rocks and Triassic limestones intensely karstified along the eastern coast. The western shoreline is characterized by Jurassic 
ophiolites of the Mirdita zone. Cenozoic sediments including Pliocene and Quaternary deposits are mainly found southwest of the lake (Wagner et al., 2009; Hoffmann et al., 2012).

Climatic conditions are strongly influenced by the proximity to the Adriatic Sea and the water bodies of lakes Ohrid and Prespa, which reduce the temperature extremes due to the presence of high mountain chains (Wagner et al., 2009; Hoffmann et al., 2012). An average precipitation for the Lake Ohrid watershed of $\sim 900 \mathrm{~mm}$ has been determined by Popovska and Bonacci (2007). Temperatures range from $\sim 10.5$ to $22.3^{\circ} \mathrm{C}$ in summer and from -2.3 to $6.6^{\circ} \mathrm{C}$ in winter. Prevailing wind directions are controlled by the basin morphology and have northern and southern provenances.

Studies on regional flora and vegetation are rather scarce in the international literature. The main source of information is from a detailed survey carried out in Galičica National Park (Matevski et al., 2011). Concerning the flora, the Mediterranean and Balkan elements dominate, but several central European species are also widespread in the area. The vegetation is organized into altitudinal belts, which develop from the lake level $(700 \mathrm{~m})$ to the top mountains $(>2200 \mathrm{~m})$ as a result of the topography.

In riparian forests, the dominant species is Salix alba. Extrazonal elements of Mediterranean vegetation are present at lower altitudes, while most forests are formed by deciduous elements. The forests appear to be rather diversified. A first belt is dominated by different species of both deciduous and semi-deciduous oaks (Quercus cerris, $Q$. frainetto, $Q$. petraea, $Q$. pubescens, and $Q$. trojana) and hornbeams (Carpinus orientalis, Ostrya carpinifolia). Proceeding towards higher altitudes, mesophilous/montane species such as Fagus sylvatica (beech), Carpinus betulus, Corylus colurna and Acer obtusatum are present. Abies alba and A. borisiiregis mixed forests grow at the upper limit of the forested area, and a sub-alpine grassland with Juniperus excelsa is found above $1800 \mathrm{~m}$ in the Mali i Thate mountains to the south-east. Alpine pasture lands and grasslands are found over the timberline, currently at around $1900 \mathrm{~m}$ (Matevski et al., 2011). The western slopes of the Galičica mountains facing Lake Ohrid are steep. The mountain's highest peaks arise from karst plateaus located at an altitude of $\sim 1600 / 1700 \mathrm{~m}$, which have been intensely grazed in the past and are now being slowly reforested.

Picea excelsa shows a disjointed distribution in the Balkans and is not present in the region of Ohrid. It is present in Mavrovo National Park (FYROM) with populations rather small-sized that can even be counted to an exact figure (Matevski et al., 2011). The same applies to $P i$ nus heldreichii. Sparse populations of Pinus sp. pl. (Klaus, 1989) are considered to be Tertiary relics and are located in the wider region of Lake Ohrid. These include populations of Pinus peuce (Macedonian pine) at high elevation in the Voras mountains in Greece (to the south-east of Lake Ohrid) (Dafis et al., 1997), and in Mavrovo (to the north) and Pelister (to the east) National Parks in FYROM (Pana- giotopoulos, 2013; Panagiotopoulos et al., 2013; http://www. exploringmacedonia.com/national-parks.nspx). Pinus peисе (Alexandrov and Andonovski, 2011) shows a high ecological adaptability. Cold mountain climate and high air humidity are the most suitable conditions for Macedonian pines. They naturally grow mainly on silicate terrains and, less often, on carbonate ones at an elevation of $800-900$ up to 2300-2400 $\mathrm{m}$ a.s.l., while the most favourable habitats occur between 1600 and $1900 \mathrm{~m}$ altitude. Pinus nigra forests are widespread in the Grammos mountains to the south-west of the lake (Dafis et al., 1997).

Lake Ohrid is well known for its rich local macrophytic flora, consisting of more than 124 species. Four successive zones of vegetation characterize the lake shores: the zone dominated by floating species such as Lemna trisulca, mainly diffused in canals, the Phragmites australis discontinuous belt around the lake, the zone dominated by Potamogeton species, and the zone dominated by Chara species (Imeri et al., 2010).

\section{Material and methods}

Details about core recovery, the core composite profile and sub-sampling are provided by Wagner et al. (2014) and Francke et al. (2016). From the DEEP site (ICDP site $5045-1)$ in the central part of Lake Ohrid $\left(41^{\circ} 02^{\prime} 57^{\prime \prime} \mathrm{N}\right.$, $020^{\circ} 42^{\prime} 54^{\prime \prime}$ E, Fig. 1), $1526 \mathrm{~m}$ of sediments with a recovery of $>95 \%$ down to $569 \mathrm{~m}$ below lake floor (mb.l.f.) have been recovered from seven different boreholes at a water depth of $243 \mathrm{~m}$. Until today, a continuous composite profile down to $247.8 \mathrm{~m}$ composite depth (mcd) with a recovery of $>99 \%$ has become available, and sub-sampling was carried out at $16 \mathrm{~cm}$ resolution (Francke et al., 2016).

\subsection{Core chronology}

The DEEP core chronology down to 247.8 mcd (Francke et al., 2016) is based on radiometric ages of 11 tephra layers (first-order tie points), and on tuning of biogeochemical proxy data to orbital parameters (second-order tie points; Laskar et al., 2004). The second-order tie points were obtained by tuning minima in total organic carbon (TOC) and TOC / TN against increasing summer insolation and winter season length. The timing of increasing summer insolation and winter season length caused cold and dry conditions in the Balkan Peninsula (Tzedakis et al., 2006; Francke et al., 2016), which may have led in Lake Ohrid to restricted primary productivity during summer and prolonged mixing and better decomposition of organic matter during winter. This likely resulted in low TOC and a low TOC / TN ratio (Francke et al., 2016). Finally, the age model for the sediment cores was refined by a comparison with the age model of the downhole logging data by Baumgarten et al. (2015). Correlation of the tephra layers with well-known eruptions of Italian 
volcanoes and a re-calibration of radiometric ages from the literature have been carried out by Leicher et al. (2015).

\subsection{Pollen analysis}

Sample processing and pollen microscope analysis are the fruit of strict cooperative work by several investigators across many European laboratories. Prior to the pollen analysis, considerable time was invested in assessing and standardizing the treatment protocol and pollen identification issues. More specifically, (1) we joined previous lists of taxa that were derived from older studies in Lake Ohrid and the western Balkans and produced a final list that has been accepted by all the analysts; (2) we thoroughly elaborated on systematic issues like synonyms and different degrees of pollen determination, particularly focusing on the identification of problematic taxa; (3) we shared pollen pictures of key taxa (e.g. oak types) and of dubious ones; (4) we also performed analyses of samples from the same core depth in different laboratories. Samples were mostly distributed in batches of consecutive samples; and (5) finally, close checks were performed at the intervals where two different analysts' samples met in order to avoid any potential identification bias.

A total of 306 sediment samples at $64 \mathrm{~cm}$ intervals down to the depth of $197.55 \mathrm{~m}$ taken from the DEEP core have been chemically processed for palynology in order to establish an overview diagram (named the skeleton diagram hereafter) spanning the past $\sim 500 \mathrm{ka}$. According to the age model by Francke et al. (2016), the mean resolution between two samples is $\sim 1600$ years.

For each sample, $1 / 1.5 \mathrm{~g}$ of dry sediment was treated with cold $\mathrm{HCl}(37 \%)$, cold $\mathrm{HF}(40 \%)$ and hot $\mathrm{NaOH}(10 \%)$. In order to estimate the pollen concentration, two tablets containing a known number of Lycopodium spores (Stockmarr, 1971) were added to each sample. To draw pollen percentage diagrams, different pollen basis sums (PS) have been used, following the criteria listed by Berglund and Ralska-Jasiewiczowa (1986). Terrestrial pollen percentages have been calculated excluding Pinus from the PS due to its high overrepresentation in a large number of samples. The Pinus percentage was calculated on a different pollen sum which includes pines.

Oak pollen has been divided into three types according to morphological features following Smit (1973): Quercus robur type, which includes deciduous oaks, Quercus ilex type including the evergreen oaks minus $Q$. suber, and Quercus cerris type, including semi-deciduous oaks and $Q$. suber. Further identifications follow Beug (2004), Chester and Raine (2001) and Reille (1992, 1995, 1998). Juniperus type includes pollen grains of Cupressus, Juniperus and Taxus. Pollen curves/diagrams (Fig. 2, 3 and 4) were drawn using the C2 program (Juggins, 2003). Ages are expressed in thousands of years BP (ka BP). Pollen zone boundaries were established with the help of CONISS (Grimm, 1987). Given the millennial temporal resolution of the skeleton diagram and considering the ongoing and planned high-resolution studies, we assigned 13 (i.e. OD-1 to OD-13) Pollen Assemblage SuperZones (PASZ, sensu Tzedakis, 1994a) that correspond to major shifts in glacial-interglacial vegetation. This approach allows for the definition of new pollen zones and subzones within these superzones as high-resolution (centennial) data from the Lake Ohrid archive will emerge.

\section{Results and discussion}

We present data in two pollen diagrams: (i) a percentage pollen diagram (main taxa) based on the sediment depth scale and including lithostratigraphy and tie points used to assess chronology of the DEEP site sequence (Francke et al., 2016, Fig. 2); (ii) a pollen diagram showing the percentage sums of ecological groups and selected concentration curves drawn according to the age scale (Fig. 3).

In total, 296 samples (97\% of the total analysed) yielded low-medium to high pollen concentrations allowing a detailed palynological analysis. Samples with counts less than 80 terrestrial pollen grains were excluded from the diagram. Mean pollen counts of 824 terrestrial pollen grains have been achieved. The physiognomy of vegetation shows maximum variability: arboreal pollen (AP) ranges from 19 to $99 \%$ (Fig. 2). The total pollen concentration of terrestrial taxa is quite variable, ranging from ca. 4000 to ca. 910000 pollen grains $\mathrm{g}^{-1}$ (Fig. 4). Lower values are found in herb-dominated glacial periods. Pollen preservation was good, allowing most times identification of individual taxa. The number of identified taxa is 175 , encompassing 143 terrestrial and 10 aquatic plants.

The main vegetation features are summarized in Table 1. The pollen record was subdivided into 13 main pollen assemblage superzones (PASZ, OD - named after the Ohrid DEEP core) on the basis of changes in AP versus non-arboreal pollen (NAP), changes in pollen concentration and major changes in single taxa. The most abundant taxon is Pinus. Given the uncertainties on the origin of the high pollen percentages of Pinus, exceeding $95 \%$ in some samples, we decided to remove Pinus from the pollen sum (Figs. 2, 3 and 4, Table 1) used as the basis for all percentage calculations. The only exception is in Fig. 3, where we also present the APNAP diagram with Pinus included in the pollen sum.

\subsection{Vegetation and climatic inferences based on the skeleton diagram}

Climate variability paces the pronounced intra-interglacial vegetational shifts inferred from the pollen record, while different patterns of ecological succession emerge during interglacials (Fig. 3).

Long-term vegetation dynamics correspond accurately to the glacial and interglacial periods, even if admittedly the established chronology for the Lake Ohrid DEEP record could 


\section{Lake Ohrid (693 m a.s.I.) FYROM / Albania - DEEP core pollen percentage diagram (selected taxa)}

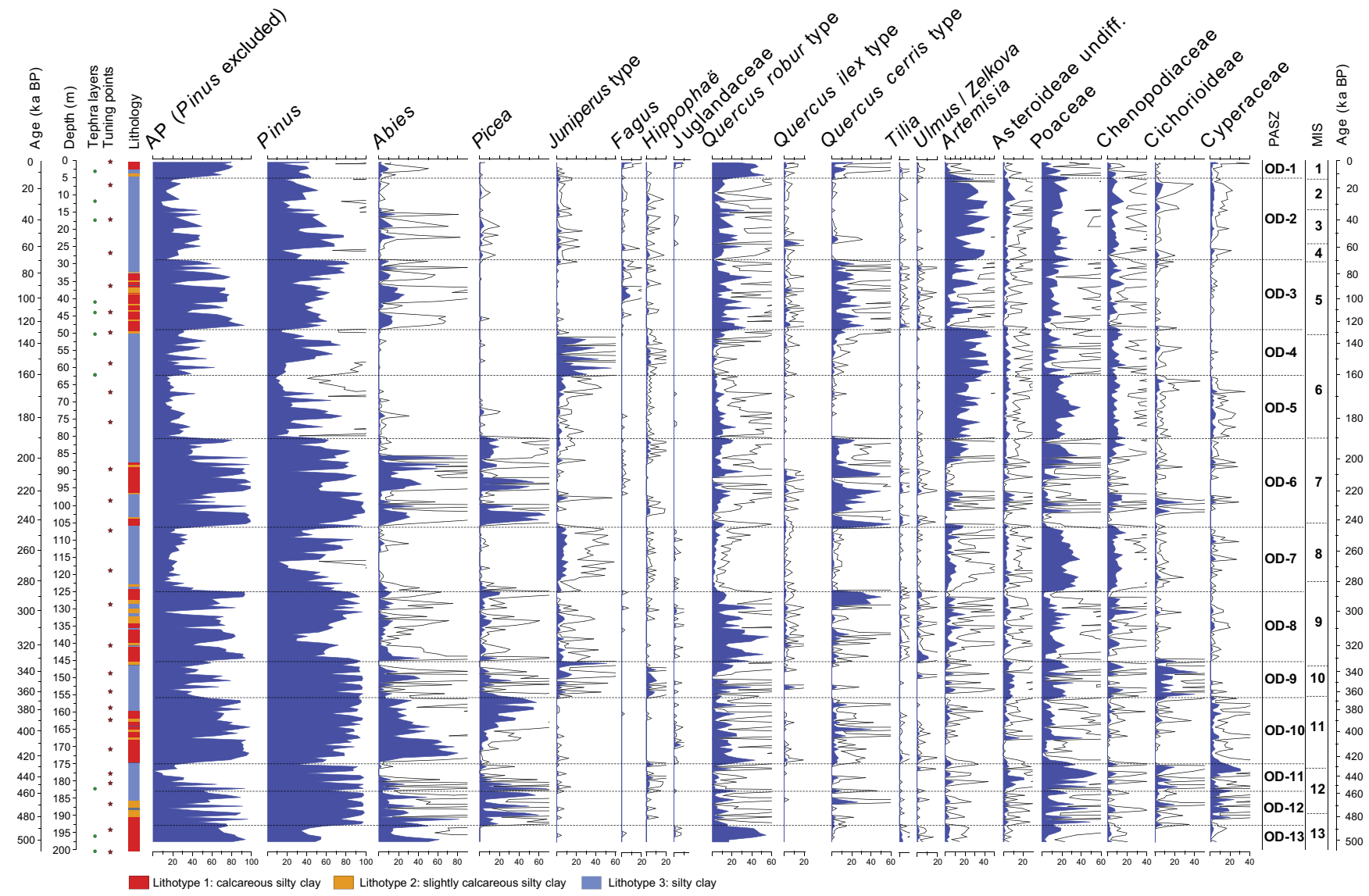

Figure 2. Lake Ohrid (FYROM), DEEP core. Pollen percentage diagram of selected taxa against depth scale. Lithology, tephra layers and tuning points adapted from Francke et al. (2016).

be further improved with tuning to higher-resolution proxy data (see Zanchetta et al., 2015), with the detection of other tephra layers and the general improving of analyses obtained for the record.

In addition, most interstadials and some higher-order variability have been previously reported from south-eastern Europe, i.e. Ioannina (MIS6: Roucoux et al., 2011) and Tenaghi Philippon (MIS8: Fletcher et al., 2013). Ongoing high-resolution studies will help define dynamics of specific taxa, revealing extinctions and detecting possible new refuge areas.

A close look at the Lake Ohrid pollen record reveals distinct characteristics for glacial and interglacial phases during the investigated past $500 \mathrm{ka}$. Glacial periods are generally characterized by dominance of NAP (e.g. Poaceae, Chenopodiaceae and Artemisia). An exception to this behaviour is found during older glacial phases (OD-12, OD-11 and OD9; Table 1) when Pinus pollen show high percentages and medium/high concentrations that appear reduced only at the end of OD-11 (Figs. 3, 4). Interglacial/interstadial periods are characterized by expansions of woodland organized in veg- etation belts (e.g. forests with Abies, Picea, Quercus robur type, $Q$. cerris type) and by increases in AP-Pinus pollen concentration. This general pattern of glacial-interglacial alternations is at times punctuated by minor expansions of AP during glacials and accordingly by forest opening (stadials) during interglacial complexes. This is in agreement with previous studies from Greece, e.g. Ioannina (Tzedakis, 1994b; Tzedakis et al., 2002; Roucoux et al., 2008, 2011) and Tenaghi Philippon (e.g. Milner et al., 2012; Fletcher et al., 2013; Pross et al., 2015), and from central Italy (Follieri et al., 1998), suggesting a sensitive response of vegetation to climate change on a regional scale in south-eastern Europe. At Lake Ohrid, most tree taxa show a rather continuous presence, even during glacial phases, suggesting that the Ohrid region has been a plant refugium. The investigation of dynamics of specific taxa and time of extinctions and the detection of possible refuge areas are among the issues that must be refined by ongoing high-resolution studies.

A clear correspondence between the climate signals provided by our terrestrial pollen record and marine oxygen isotope records (Fig. 4) is apparent, even if the limits between 


\section{Lake Ohrid (693 m a.s.I.) FYROM / Albania - DEEP core pollen diagram (selected groups / taxa)}

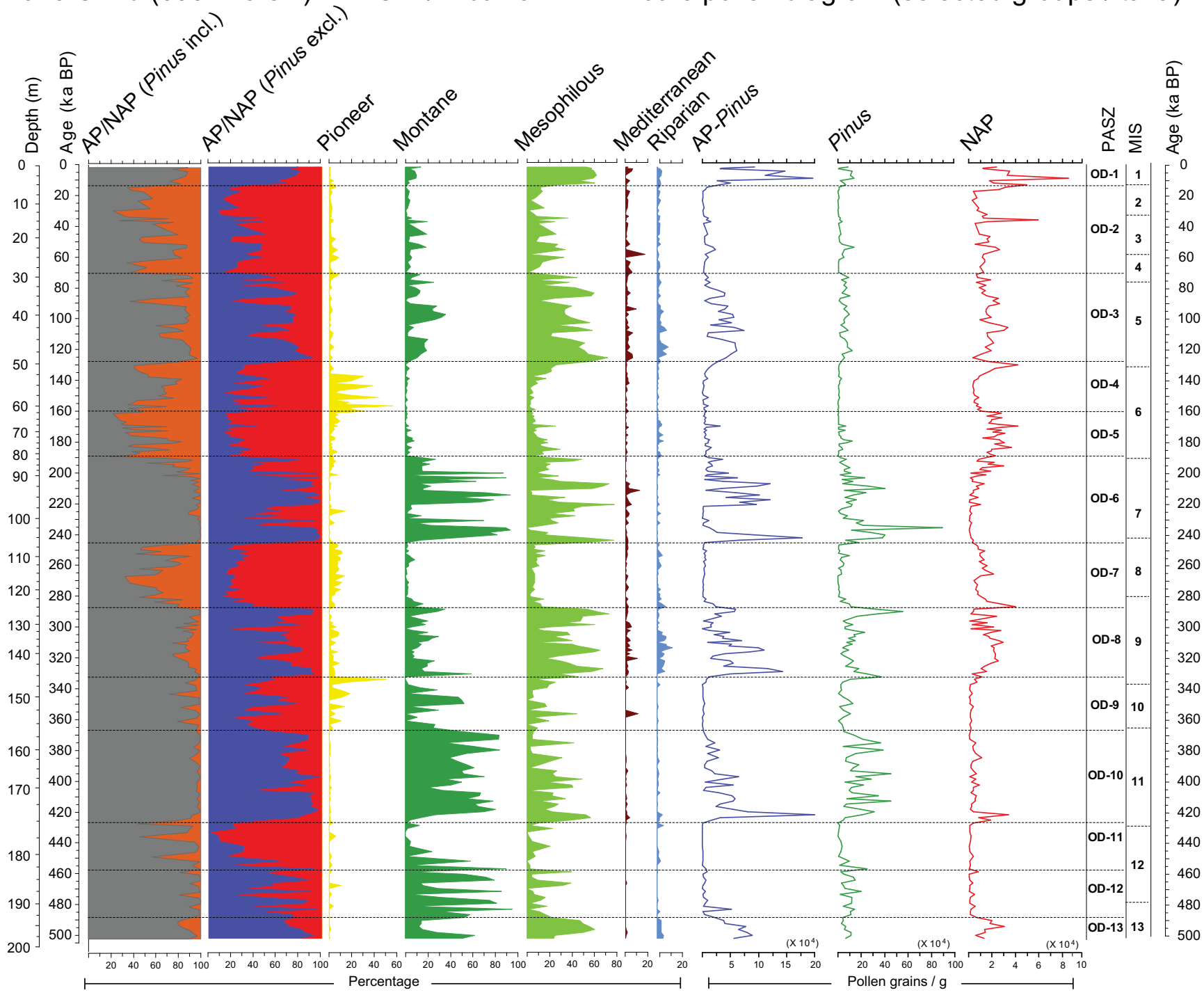

Figure 3. Lake Ohrid (FYROM), DEEP core. Pollen diagram of selected ecological groups (\%) and concentration curves against chronology (Francke et al., 2016). Ecological groups: montane trees (Abies, Betula, Fagus, Ilex, Picea, Taxus); mesophilous trees (Acer, Buxus, Carpinus betulus, Castanea, Carya, Celtis, Corylus, Fraxinus excelsiorloxycarpa, Ostrya/Carpinus orientalis, Pterocarya, Hedera, Quercus robur type, Quercus cerris type, Tilia, Tsuga, Ulmus, Zelkova); mediterranean trees (Arbutus, Fraxinus ornus, Cistus, Olea, Phillyrea, Pistacia, Quercus ilex, Rhamnus); riparian trees (Salix, Platanus, Populus, Alnus, Tamarix); pioneer shrubs (Ephedra, Juniperus type, Ericaceae, Hippophaё).

pollen zones and marine isotope stages are often not identical (Figs. 2, 3).

Glacial periods (PASZ OD-12, 11, 9, 7, 5, 4, 2, Table 1) are generally characterized by dominance of Poaceae, Artemisia, and Chenopodiaceae that are indicative of open environments around the lake. Poaceae probably include aquatic macrophytes from the lacustrine belt and herbs from grassland formations in the catchment of Lake Ohrid. Artemisia and Chenopodiaceae, which are typically components of steppe-desert environments, consist of shrub and sub-shrub species. In OD-12/11 and OD-9, high percentages of Pinus can either point to the local presence of widespread thickets like those currently growing at very high elevations in the surroundings of the lake, or to transport from a long distance in a barren land. Another aspect to consider is that a large lake such as Ohrid could partially resemble the marine realm, leading to over-representation of pollen grains that float easily. But this should be a constant factor in the analysed records, unless big changes in the lake surface occurred. The available seismic data, not completely processed yet, suggest anyway (K. Lindhorst and S. Krastel, personal 


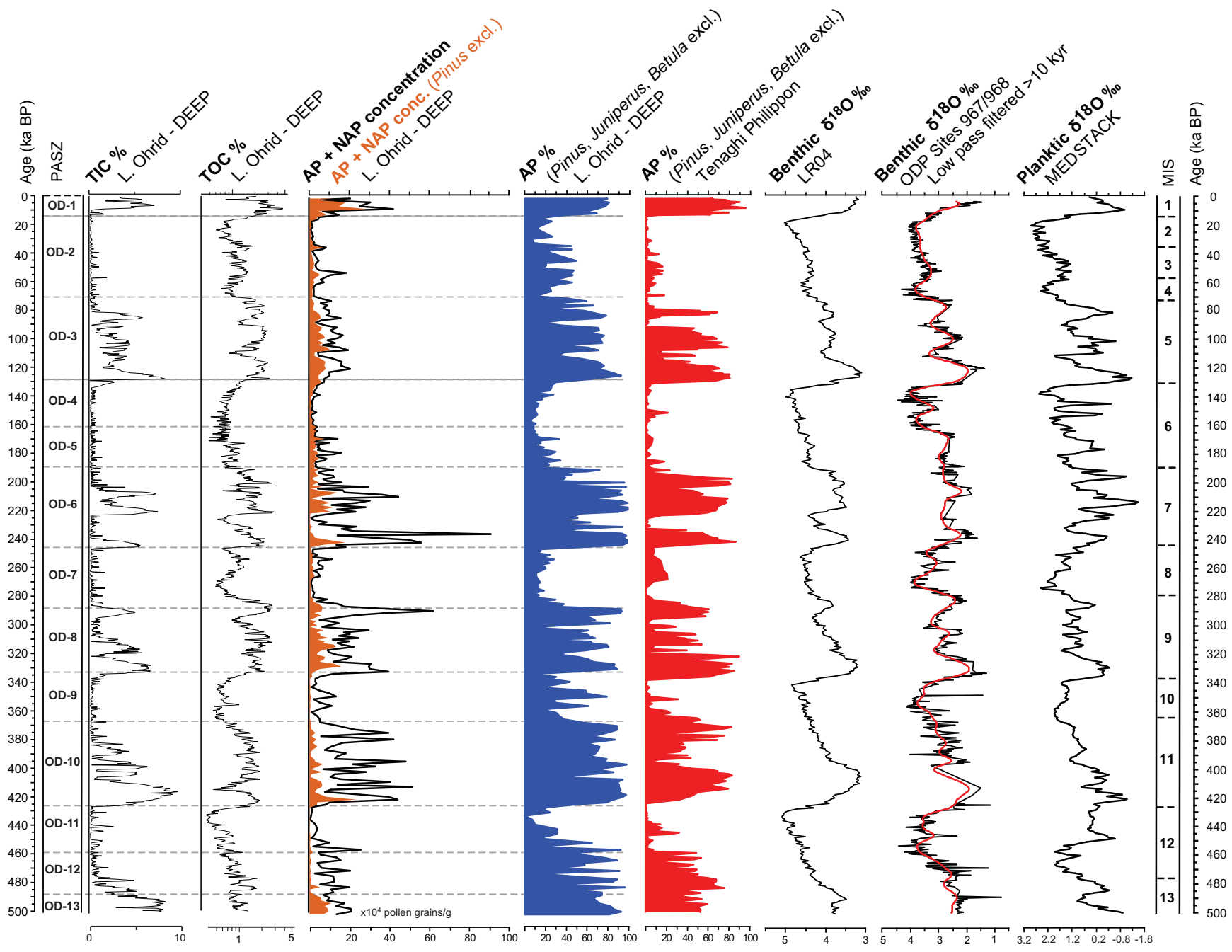

Figure 4. Comparison of selected proxies from Lake Ohrid with other records spanning the last 500 ka drawn against original age models. Lake Ohrid: total organic carbon, TOC, total inorganic carbon, TIC (Francke et al., 2016); total pollen concentration of terrestrial plants $(\mathrm{AP}+\mathrm{NAP})$ and the same without Pinus, AP percentages (this study). Tenaghi Philippon: AP \% excluding Pinus, Betula and Juniperus (Wijmstra, 1969 and Wijmstra and Smit, 1976; age model from Tzedakis et al., 2006). Marine records: LR04 $\delta^{18}$ O benthic stack (Lisiecki and Raymo, 2005); stacked benthic $\delta^{18} \mathrm{O}$ data for ODP sites 967 and 968 from the eastern Mediterranean (Konijnendijk et al., 2015); MEDSTACK planktic $\delta^{18} \mathrm{O}$ data (Wang et al., 2010).

comments, 2015) that the lake size was not significantly different prior to $330 \mathrm{ka}$.

In contrast, interglacial complexes (PASZ OD-13, 10, 8, 6,3 and 1 , Table 1) are marked by expansions of woods dominated by Abies, Picea, the Quercus robur type and the $Q$. cerris type. This pattern is at times punctuated by minor expansions of AP during glacial periods and by forest opening during interglacial ones.

The pollen diagram shows that, in the past $285 \mathrm{ka}$ (PASZ OD-7 to OD-1), non-forested periods (herb-dominated) prevailed and that their duration was longer than between 500 and $285 \mathrm{ka}$. Forest phases show wetter and cooler conditions in the lower part of the diagram (PASZ OD-13 to OD-8, 502$288 \mathrm{ka}$ ) as indicated by the dominance of conifers, while in the upper part (PASZ OD-3 and OD-1, $129 \mathrm{ka}$-present) there was a "general" increasing trend in temperature indicated by the presence of mesophilous broadleaved trees. In OD$6(245-190 \mathrm{ka})$ a balanced alternation of the two vegetation "types" can be observed.

This general trend is visible in the reduction of montane trees present in OD-10 and 12 (roughly corresponding to MIS11 and 13) and the expansion of mesophilous and Mediterranean taxa in the present and penultimate interglacials (Fig. 3). The pre-penultimate interglacial (OD-8, 333-288 ka, cf. MIS9) shows increased mesophilous trees. The penultimate interglacial (OD-6, 245-190 ka, cf. MIS7) shows intermediate features, with balanced presence of montane and mesophilous taxa. This trend seems to be con- 
Table 1. Main vegetational features of Lake Ohrid DEEP core pollen assemblage zones (OD-PASZ) and related chronological limits. The basis sum for AP and NAP taxa does not include Pinus (see text).

\begin{tabular}{|c|c|c|}
\hline PASZ & & Zone description \\
\hline OD-1 & $\begin{array}{l}\text { Depth limits }(\mathrm{m}) 5-0 \\
\text { Age limits }(\mathrm{ka}) 14-0 \\
\text { Duration }(\mathrm{ka}) 14 \\
\text { Pollen sample no. } 9 \\
\text { Mean pollen count } 353\end{array}$ & $\begin{array}{l}\text { Mesophilous tree taxa prevail. Forests are characterized by the Quercus robur type }(22-43 \%) \\
\text { and the } Q . \text { cerris type }(2-21 \%) \text {. Montane taxa are quite scarce and mainly represented by } \\
\text { Abies and Fagus. Riparian and mediterranean trees are not abundant either. } \\
\text { Poaceae are dominant among herbs. Pollen concentration is high. }\end{array}$ \\
\hline OD-2 & $\begin{array}{l}\text { Depth limits (m) } 29-5 \\
\text { Age limits (ka) } 70-14 \\
\text { Duration (ka) } 56 \\
\text { Pollen sample no. } 26 \\
\text { Mean pollen count } 270\end{array}$ & $\begin{array}{l}\text { Open vegetation (steppe) with low/medium values of Pinus }(9-77 \%) \\
\text { and sparse presence of many montane and mesophilous taxa. Among them } \\
\text { the } Q . \text { robur type is worth mentioning. Artemisia is the most } \\
\text { abundant taxon and is accompanied by other herbs like Poaceae, Chenopodiaceae } \\
\text { and Cyperaceae. Pollen concentration shows medium values. }\end{array}$ \\
\hline OD-3 & $\begin{array}{l}\text { Depth limits (m) } 48-29 \\
\text { Age limits (ka) } 129-70 \\
\text { Duration (ka) } 59 \\
\text { Pollen sample no. } 31 \\
\text { Mean pollen count } 660\end{array}$ & $\begin{array}{l}\text { Alternation of periods characterized by mesophilous/montane trees and open vegetation. } \\
\text { Forests are mainly characterized by expansion of the } Q . \text { cerris type }(2-33 \%) \\
\text { and the } Q . \text { robur type ( } 4-40 \%) \text { together with Abies and Fagus, } \\
\text { this last one reaching the highest values of the diagram in this zone. } \\
\text { Riparian and Mediterranean trees are present. Artemisia, Poaceae } \\
\text { and Chenopodiaceae characterize the open vegetation. Pollen concentration is high. }\end{array}$ \\
\hline OD-4 & $\begin{array}{l}\text { Depth limits (m) } 62-48 \\
\text { Age limits (ka) } 160-129 \\
\text { Duration (ka) } 31 \\
\text { Pollen sample no. } 21 \\
\text { Mean pollen count } 352\end{array}$ & $\begin{array}{l}\text { Open vegetation (steppe) with medium/high values of Pinus }(14-83 \%) \text {. } \\
\text { Juniperus }(0-55 \%) \text { and Hippophaë }(0-5 \%) \text { are important woody } \\
\text { taxa. Mesophilous taxa are present even if with low values. Herbs are overwhelming: } \\
\text { Artemisia shows a sudden increase, while Poaceae and Cyperaceae are reduced; } \\
\text { Chenopodiaceae are abundant. Pollen concentration shows medium values. }\end{array}$ \\
\hline OD-5 & $\begin{array}{l}\text { Depth limits (m) } 80-62 \\
\text { Age limits (ka) } 190-160 \\
\text { Duration (ka) } 30 \\
\text { Pollen sample no. } 28 \\
\text { Mean pollen count } 320\end{array}$ & $\begin{array}{l}\text { Open vegetation with medium values of Pinus }(6-75 \%) \text {, Juniperus }(0-9 \%) \\
\text { and Hippophaë. Many mesophilous taxa are present even if with low values. } \\
\text { Herbs are overwhelming: Poaceae, Artemisia, Chenopodiaceae and } \\
\text { Cyperaceae are abundant. Pollen concentration has medium values. }\end{array}$ \\
\hline OD-6 & $\begin{array}{l}\text { Depth limits }(\mathrm{m}) 106-80 \\
\text { Age limits }(\mathrm{ka}) 245-190 \\
\text { Duration }(\mathrm{ka}) 55 \\
\text { Pollen sample no. } 41 \\
\text { Mean pollen count } 1484\end{array}$ & $\begin{array}{l}\text { Alternation of coniferous and mesophilous forests with grassland (steppe) formations. } \\
\text { Main conifer taxa are Pinus }(24-99 \%) \text {, Abies }(0-77 \%) \text { and Picea }(0-67 \%) \text {; } \\
Q . \text { cerris }(0-21 \%) \text { is the dominant mesophilous taxon, being more abundant } \\
\text { than the } Q . \text { robur type }(0-30 \%) \text {. Poaceae are accompanied by high values of Chenopodiaceae, } \\
\text { Cichorioideae and Artemisia. Pollen concentration is quite variable, } \\
\text { oscillating from almost the highest to almost the lowest values of the record. }\end{array}$ \\
\hline OD-7 & $\begin{array}{l}\text { Depth limits (m) } 125-106 \\
\text { Age limits (ka) } 288-245 \\
\text { Duration (ka) } 43 \\
\text { Pollen sample no. } 27 \\
\text { Mean pollen count } 605\end{array}$ & $\begin{array}{l}\text { Open vegetation with high values of pioneer taxa (mainly Juniperus). } \\
\text { Pinus is very abundant (10-87\%). } \\
\text { Poaceae are very abundant, accompanied by Chenopodiaceae and Artemisia. } \\
\text { Pollen concentration is very low. }\end{array}$ \\
\hline OD-8 & $\begin{array}{l}\text { Depth limits }(\mathrm{m}) 145-125 \\
\text { Age limits }(\mathrm{ka}) 333-288 \\
\text { Duration }(\mathrm{ka}) 45 \\
\text { Pollen sample no. } 31 \\
\text { Mean pollen count } 804\end{array}$ & $\begin{array}{l}\text { Mesophilous tree taxa prevail. Forests are characterized by the Quercus robur type }(5-55 \%) \\
\text { and the } Q \text {. cerris type }(0-50 \%) \text {. Riparian and mediterranean trees are worth mentioning. } \\
\text { Poaceae are dominant among herbs. Pollen concentration is high. }\end{array}$ \\
\hline OD-9 & $\begin{array}{l}\text { Depth limits }(\mathrm{m}) 155-145 \\
\text { Age limits }(\mathrm{ka}) 366-333 \\
\text { Duration }(\mathrm{ka}) 33 \\
\text { Pollen sample no. } 16 \\
\text { Mean pollen count } 438\end{array}$ & $\begin{array}{l}\text { Open vegetation with relatively high values of pioneer taxa. Pinus }(60-98 \%) \text {, } \\
\text { the Juniperus type and Hippophä are rather abundant. Picea }(0-43 \%) \\
\text { and Abies }(0-63 \%) \text { are mainly found in the middle of the zone. } \\
\text { Peaks of mesophilous taxa are also observed. Poaceae, Chenopodiaceae, Asteroideae, } \\
\text { Cichorioideae and Artemisia are very abundant. Pollen concentration is low. }\end{array}$ \\
\hline
\end{tabular}


Table 1. Continued.

\begin{tabular}{|c|c|c|}
\hline PASZ & & Zone description \\
\hline OD-10 & $\begin{array}{l}\text { Depth limits (m) } 175-155 \\
\text { Age limits (ka) } 428-366 \\
\text { Duration (ka) } 62 \\
\text { Pollen sample no. } 31 \\
\text { Mean pollen count } 1665\end{array}$ & $\begin{array}{l}\text { Forests characterized first by the Quercus robur type }(0-43 \%) \\
\text { and the } Q \text {. cerris type }(0-40 \%) \text {, then by long-term successions of Abies }(1-80 \%) \text {, } \\
\text { and Picea montane woods. } \\
\text { Poaceae are most dominant among the herbs. Pollen concentration is high. }\end{array}$ \\
\hline OD-11 & $\begin{array}{l}\text { Depth limits (m) } 183-175 \\
\text { Age limits (ka) } 459-428 \\
\text { Duration (ka) } 31 \\
\text { Pollen sample no. } 12 \\
\text { Mean pollen count } 810\end{array}$ & $\begin{array}{l}\text { Open vegetation with relatively high values of pioneer taxa. Pinus }(28-98 \%) \\
\text { and Hippophaë are very abundant. Picea }(0-67 \%) \text { and } \\
\text { Abies }(0-26 \%) \text { are mainly found in the lowermost samples of the zone. } \\
\text { Poaceae, Cyperaceae, Chenopodiaceae, Asteroideae, Cichorioideae and Artemisia } \\
\text { are very abundant. Pollen concentration is the lowest of the entire record. }\end{array}$ \\
\hline OD-12 & $\begin{array}{l}\text { Depth limits (m) } 193-183 \\
\text { Age limits (ka) } 488-459 \\
\text { Duration (ka) } 29 \\
\text { Pollen sample no. } 16 \\
\text { Mean pollen count } 1513\end{array}$ & $\begin{array}{l}\text { Forests dominated by Pinus }(58-98 \%) \text {, Abies }(2-82 \%) \\
\text { and Picea }(1-60 \%) \text { are alternating with open vegetation dominated by Poaceae, } \\
\text { Cyperaceae, Chenopodiaceae, Cichorioideae and Artemisia. } \\
\text { Pollen concentration is relatively low. }\end{array}$ \\
\hline OD-13 & $\begin{array}{l}\text { Depth limits (m) } 198-193 \\
\text { Age limits (ka) } 502-488 \\
\text { Duration (ka) } 14 \\
\text { Pollen sample no. } 7 \\
\text { Mean pollen count } 342\end{array}$ & $\begin{array}{l}\text { Mesophilous and montane tree taxa prevail. Forests first with Abies }(11-51 \%) \\
\text { and then with the Q.robur type }(16-54 \%) \text {. } \\
\text { Poaceae are dominant among herbs. Pollen concentration is high. }\end{array}$ \\
\hline
\end{tabular}

firmed also by herbs: Poaceae and Cyperaceae decrease, while Artemisia and Chenopodiaceae increase towards the top of the diagram. Steppes and steppe forests seem to characterize the last two glacial periods.

OD-12 (488-459 ka) shows a dominance of AP and the overwhelming presence of pine pollen. This suggests that this period, corresponding to the first part of the MIS12 glacial phase, could have been cold but not very dry, so that conifer montane taxa such as Pinus, Picea and Abies were growing in the lake basin. In the following zone OD-11 (459-428 ka), stronger glacial conditions are evidenced by decreased AP and increased herbs. The curve of Hippophä̈, the only arboreal plant with increasing percentages (Fig. 2), confirms this interpretation. The climate of this glacial phase was anyway wetter than the following ones, as evidenced by the permanence of both trees and the expansion of Cyperaceae. The relative humidity recorded at Lake Ohrid during the second part of MIS12 (OD-11) is consistent with the high endemism and biodiversity of the site. The buffering capacity of the lake has to be considered together with the possibility that a part of pine pollen could be from Pinus peuce, a species with high ecological plasticity, which currently has only a relict distribution and is adapted to cold and moist conditions (Aleksandrov and Andonovski, 2011). The surrounding area of the lake could have acted as a refugium for conifers such as Macedonian pines. The relatively low abundance of the xerophytic Mediterranean "ecogroup" also supports this view.

If we do not consider pine, the passage to the following interglacial (OD-10, 428-366 ka) is marked by an important and multi-millennial-long expansion of Abies (accompanied by the Quercus robur type) followed by a $\sim 10$ ka-long expansion of Picea (accompanied by the Quercus cerris type). This vegetation pattern indicates that the first part of this interglacial was warmer and wetter than the second one. Moreover, this long-term succession, which has also been documented in Praclaux (de Beaulieu et al., 2001) and in the central European lowlands (Koutsodendris et al., 2010), is not represented in the rest of the diagram, pointing to the unique character of MIS 11. Both fir (Abies) and spruce (Picea) could have occupied the montane belt (with pines at higher elevations or in poor soils), while deciduous oaks (Quercus robur type) first, and subsequently semi-deciduous oaks (Quercus cerris type), were most likely growing at lower elevations.

Glacial conditions prevailed during zone OD-9, 366$333 \mathrm{ka}$ (cf. MIS10), even if oscillations of mesophilous trees occurred and alternated with herb expansions. Cichorioideae, together with Asteraceae undiff., characterized the herbaceous vegetation, although their values may be increased in the pollen profile because of taphonomic issues that still need to be further investigated.

The following interglacial OD-8, 333-288 ka (cf. MIS9), shows a three-phase widespread mesophilous arboreal expansion. The Quercus robur type prevailed in the first and longer phase, while the $Q$. cerris type at the end of the zone indicated a successive change from warmer and wetter to cooler and drier conditions interrupted by short cool events (NAP increases). 
OD-7, 288-245 ka (cf. MIS8) shows low AP percentages (pioneer vegetation mainly consisting of the Juniperus type is rather abundant) and increased values of Poaceae. Even if Poaceae pollen could originate from the Phragmites lacustrine vegetation belt, such high values are mainly ascribed to the presence of regional grasslands that are typical for glacial periods in south-eastern Europe (e.g. Tzedakis et al., 2001; Pross et al., 2015).

OD-6 (245-190 ka) shows a very high forest variability, with three expansions of trees interrupted by two herb expansions. This interglacial/interstadial complex, possibly corresponding to MIS7, has a vegetation behaviour quite different from that of MIS9 and MIS11. MIS7 at Lake Ohrid is marked by warmer and wetter conditions as suggested by decreasing Abies and increasing Picea percentages. The first NAP increase is characterized by many taxa with similar values (Poaceae, Chenopodiaceae, Artemisia and other Asteroideae): the second one by Poaceae and the first strong increase in the Artemisia percentage in the diagram.

A long glacial phase is represented in OD-5 (190$160 \mathrm{ka})$ and OD-4 (160-129 ka). The limit between the two open formations is marked by a change from a grasslanddominated environment (Poaceae and Cyperaceae) to a steppe-dominated (Artemisia) one. Dry conditions are also indicated by a decreasing Quercus robur type and an increasing $Q$. cerris type together with Juniperus type and Hippophä percentages. The second part of MIS6 (OD-4) appears to be the driest phase of the diagram. This is in good agreement with hydro-acoustic data and sediment core analyses from the north-eastern corner of Lake Ohrid, which revealed that during MIS6 the water surface of the lake was $60 \mathrm{~m}$ lower than today (Lindhorst et al., 2010). Similarly, sedimentological data from the DEEP core (Francke et al., 2016) show that an accumulation of thin mass movement deposits (MMD) occurred during the second part of MIS6, which might be also indicative of low lake levels.

Forests of OD-3, 129-70 ka (cf. MIS5) are characterized by less variability than the previous OD-6 interglacial/interstadial complex. Mesophilous communities prevailed on the montane vegetation. Quercus robur type and $Q$. cerris type values are rather similar. Picea is very rare and Fagus shows the highest values of the entire record. Similarly to all previous interglacials, the vegetation seems to be organized in altitudinal belts. Periods with open vegetation are featured by expansions of Artemisia, Chenopodiaceae and Poaceae.

The last glacial period, i.e. MIS4-2, is represented in PASZ OD-2 (70-14 ka). It has a rather high variability, evidenced, already at this step of analysis, by important oscillations of most trees.

The present interglacial is characterized by the strong and prominent expansion of the Quercus robur type accompanied by the $Q$. cerris type and relatively low montane taxa such as Abies and Fagus. The uppermost samples show opening of the landscape by humans, with evidence of crops and spreading of fruit trees such as Juglans (included in Juglandaceae in Fig. 2). The reduced presence of Picea matches both the palynological data from Lake Prespa for the last glacial (Panagiotopoulos et al., 2014) and the present-day vegetation features of FYROM, where spruce is represented by relic populations in few forested areas. During the penultimate glacial (MIS6), Picea populations were probably too near to their tolerance limit to survive. The importance of ecological thresholds for temperate trees was carefully investigated in three Greek records located in contrasting bioclimatic areas (Ioannina, Kopais, Tenaghi Philippon; Tzedakis et al., 2004a). This turned out to be crucial to understand the importance of local factors in modulating the biological response to climatic stress that occurred in the last glacial and to comprehend the present-day distribution of arboreal species in the Balkans.

\subsection{Comparison with other proxies and outlook}

In Fig. 4 alignment of the TOC, TIC, AP percentages and AP + NAP concentrations from Lake Ohrid (and "ecogroup" curves of Fig. 3) with both Tenaghi Philippon AP \% (Tzedakis et al., 2006) and marine isotope curves shows a very good general agreement between the different records. TOC and AP + NAP (pollen of terrestrial plants) concentration as well as AP\% show the same main changes, indicating that there is a tight coupling between the plant biomass and the organic carbon deposited in the lake. TIC increases are mostly in phase with vegetation changes too. The main discrepancies between both TIC / TOC and pollen data are found during glacial phases OD-12 (488-459 ka) and OD-9 (368-333 ka).

The similarity between Lake Ohrid and Tenaghi Philippon curves is striking. All the main changes in forest cover match, and they both correspond to marine records too. There are some differences in the timing of the onset of interglacial phases. DEEP core chronology benefited in fact from the presence of several tephra layers (see Fig. 2, Leicher et al., 2015). The main difference with Tenaghi Philippon is in the fact that arboreal taxa show a continuous presence at Lake Ohrid, even during the glacials, while at Tenaghi Philippon they often disappear to spread again during the interglacials, often with a certain delay. This behaviour could anyway have been expected considering the differences in water availability at the two sites. In Greece, not only Tenaghi Philippon, but also the Kopais (Okuda et al., 2001) areas, resulted in not being ideal refugia for mesophilous trees (Tzedakis et al., 2004a). A quite different situation is found at Ioannina (western Greece), a refugial site for temperate trees featuring sub-Mediterranean climate and vegetation in the last $\sim 480$ ka (Tzedakis, 1994b; Tzedakis et al., 2002, 2004a).

Besides a close correspondence to the Tenaghi Philippon AP \% curve, Fig. 4 also shows a close correspondence between our pollen data and the Mediterranean benthic and planktic composite curves (Wang et al., 2010; Konijnendijk 
et al., 2015). Compared to the global isotope stack (Lisiecki and Raymo, 2005; Railsback et al., 2015), additional detail in the pollen diagram is clearly representative of regional Mediterranean conditions and of the influence of moisture availability on the expansion of plants. Both marine deep and surface water features show additional warm phases during interglacials that are also observed in the pollen data. For example, the tripartite forests during MIS7 are well reflected in the pollen data but likely overprinted by the effect of ice volume in the global benthic isotope stack. Completion of the downcore analysis of the DEEP core from Lake Ohrid will allow for a more accurate correlation of the entire sequence with the orbitally tuned Mediterranean isotope records, and provide a finer tuning of the present age model (Francke et al., 2016) to independently dated records in the Mediterranean region where available.

\section{Conclusions}

The 500 ka long DEEP pollen record from Lake Ohrid represents a continuous documentation of the vegetation and climate history of the western Balkan region. Palynological data are complemented by many sedimentological proxies highlighting the need for a multi-disciplinary approach in palaeoenvironmental studies (see all other articles of this special issue).

The richness of pollen diversity and continuity along this long-time series point to the particular climatic and environmental conditions that contributed to the high plant diversity encountered at Ohrid at present. This has deep roots in the past, as the lake has probably acted as a permanent water reservoir providing moisture to its surroundings even during dramatic dry or cold climatic phases. In fact trees never disappeared from the investigated area.

The main novelty of this pollen record from the Balkan Peninsula is summarized by the following key findings.

- The continuous record of glacial-interglacial vegetation successions shows that refugial conditions occurred in the Lake Ohrid area. Tree extinction, whose timing and patterns need accurate checks and refined analyses, will be focused on in a dedicated study.

- A clear shift from relatively cool/humid interglacial conditions prior to $288 \mathrm{kaBP}$, to warmer and drier ones during recent interglacial periods (last $\sim 130 \mathrm{ka}$ ), suggests changing patterns toward a more Mediterraneantype climate. During the period that occurred between 245 and $190 \mathrm{ka}$ (MIS7), a very high forest variability is found during interglacials and interstadials. Glacial features, generally characterized by grasslands until $245 \mathrm{kaBP}$ and then by steppes, also confirm this climate shift.
- Similarities and dissimilarities with other southern European and Near Eastern pollen records, even if already visible, will be better defined with the improvement of analyses through ongoing high-resolution studies.

- A close correspondence of interglacial and glacial climate and vegetation evolution to regional benthic and planktic isotope data is apparent. The Ohrid pollen record integrates temperature data from the marine stratigraphy, with a clear indication of humidity/dryness changes.

Author contributions. This article is the product of strict cooperative work among palynologists who all contributed to the Lake Ohrid pollen analysis and its interpretation. The manuscript was written by L. Sadori with substantial contribution of T. H. Donders, A. Koutsodendris and K. Panagiotopoulos. A. Masi (c.a.) was responsible for data management and refined diagrams drawn by T. H. Donders and A. Koutsodendris. All coauthors contributed to the writing of this paper.

Acknowledgements. The authors are indebted to the two referees Thomas Litt and Chronis Tzedakis for the constructive comments that were used to improve the paper. Chronis Tzedakis was also of great help in giving hints to better anchor the chronology of the record.

We also thank Zlatko Levkov for organizing the SCOPSCO meeting in Skopje (2015) that gave the opportunity to A. Koutsodendris, A. Masi, K. Panagiotopoulos, L. Sadori and T. H. Donders to discuss with Valdo Matevski, botanist expert in the vegetation of Lake Ohrid, several aspects of the pollen diagram. The help of Valdo Matevski was valuable in figuring out some possible arboreal dynamics of the past. A. Koutsodendris, A. Masi, K. Panagiotopoulos, L. Sadori and T. H. Donders would also like to express their gratitude to Renata Kysterevska, Slavcho Hristovski and Mitko Kostadinovski from the University of Ss. Cyril and Methodius in Skopje for botanical literature and herbarium consultations.

The SCOPSCO Lake Ohrid drilling campaign was funded by ICDP, the German Ministry of Higher Education and Research, the German Research Foundation (DFG), the University of Cologne, the British Geological Survey, the INGV and CNR of Italy, and the governments of the Republic of Macedonia (FYROM) and Albania. Logistic support was provided by the Hydrobiological Institute in Ohrid. Drilling was carried out by Drilling, Observation and Sampling of the Earth's Continental Crust's (DOSECC) and using the Deep Lake Drilling System (DLDS). Special thanks are due to Beau Marshall and the drilling team. Ali Skinner and Martin Melles provided immense help and advice during logistic preparation and the drilling operation. A. Koutsodendris received funding from the German Research Foundation (grant KO4960/1).

Edited by: T. Wilke 


\section{References}

Albrecht, C. and Wilke, T.: Lake Ohrid: biodiversity and evolution, Hydrobiologia, 615, 103-140, 2008.

Alexandrov, A. H. and Andonovski, V.: EUFORGEN Technical Guidelines for genetic conservation and use of Macedonian pine (Pinus peuce), Bioversity International, Rome, Italy, 6 pp., 2011.

Baumgarten, H., Wonik, T., Tanner, D. C., Francke, A., Wagner, B., Zanchetta, G., Sulpizio, R., Giaccio, B., and Nomade, S.: Age-depth model of the past $630 \mathrm{kyr}$ for Lake Ohrid (FYROM/Albania) based on cyclostratigraphic analysis of downhole gamma ray data, Biogeosciences, 12, 7453-7465, doi:10.5194/bg-12-7453-2015, 2015.

Bennett, K. D., Tzedakis, P. C., and Willis, K. J.: Quaternary refugia of north European trees, J. Biogeogr., 18, 103-115, 1991.

Berglund, B. E. and Ralska-Jasiewiczowa, M.: Pollen analysis and pollen diagrams, in: Handbook of Holocene Palaeoecology and Palaeohydrology, edited by: Berglund, B. E., John Wiley \& Sons, Chichester, 455-496, 1986.

Beug, H.-J.: Leitfaden der Pollenbestimmung für Mitteleuropa und angrenzende Gebiete, Verlag Dr. Friedrich Pfeil, München, Germany, 2004.

Brauer, A., Allen, J. R. M., Mingram, J., Dulski, P., Wulf, S., and Huntley, B.: Evidence for last interglacial chronology and environmental change from Southern Europe, P. Natl. Acad. Sci. USA, 104, 450-455, 2007.

Cheddadi, R., Vendramin, G. G., Litt, T., François, L., Kageyama, M., Lorentz, S., Laurent, J. M., de Beaulieu, J. L., Sadori, L., Jost, A., and Lunt, D.: Imprints of glacial refugia in the modern genetic diversity of Pinus sylvestris, Global Ecol. Biogeogr., 15, 271-282, 2006.

Chester, P. I. and Raine, J. I.: Pollen and spore keys for Quaternary deposits in the northern Pindos Mountains, Greece, Grana, 40, 299-387, 2001.

Cvetkoska, A., Levkov, Z., Reed, J., Wagner, B., Panagiotopoulos, K., Leng, M., and Lacey, J.: Quaternary climate change and Heinrich events in the southern Balkans: Lake Prespa diatom palaeolimnology from the last interglacial to present, J. Paleolimnol., 53, 215-231, 2015a.

Cvetkoska, A., Jovanovska, E., Francke, A., Tofilovska, S., Vogel, H., Levkov, Z., Donders, T. H., Wagner, B., and WagnerCremer, F.: Ecosystem regimes and responses in a coupled ancient lake system from MIS $5 b$ to present: the diatom record of lakes Ohrid and Prespa, Biogeosciences Discuss., 12, 1505115086, doi:10.5194/bgd-12-15051-2015, 2015b.

Dafis, S., Papastergiadou, E., Georghiou, K., Babalonas, D., Georgiadis, T., Papageorgiou, M., Lazaridou, T., and Tsiaoussi, V.: Directive 92/43/EEC: The Project "Habitat" in Greece: Network Natura 2000, DG XI Commission of the European Communities - Goulandris Museum of Natural History - Greek Biotope/Wetland Center, Athens, Greece, 1997.

Djamali, M., de Beaulieu, J.-L., Shah-hosseini, M., Andrieu-Ponel, V., Ponel, P., Amini, A., Akhani, H., Leroy, S. A. G., Stevens, L., Lahijani, H., and Brewer, S.: A late Pleistocene long pollen record from Lake Urmia, NW Iran, Quaternary Res., 69, 413420, 2008

Fletcher, W. J., Sánchez Goñi, M. F., Allen, J. R. M., Cheddadi, R., Combourieu-Nebout, N., Huntley, B., Lawson, I., Londeix, L., Magri, D., Margari, V., Müller, U. C., Naughton, F., Novenko, E., Roucoux, K., and Tzedakis, P. C.: Millennial-scale variability during the last glacial in vegetation records from Europe, Quaternary Sci. Rev., 29, 2839-2864, 2010.

Fletcher, W. J., Müller, U. C., Koutsodendris, A., Christanis, K., and Pross, J.: A centennial-scale record of vegetation and climate variability from 312 to $240 \mathrm{ka}$ (Marine Isotope Stages 9c-a, 8 and 7e) from Tenaghi Philippon, NE Greece, Quaternary Sci. Rev., 78, 108-125, 2013.

Föller, K., Stelbrink, B., Hauffe, T., Albrecht, C., and Wilke, T.: Constant diversification rates of endemic gastropods in ancient Lake Ohrid: ecosystem resilience likely buffers environmental fluctuations, Biogeosciences, 12, 7209-7222, doi:10.5194/bg12-7209-2015, 2015.

Follieri, M., Magri, D., and Sadori, L.: 250,000-year pollen record from Valle di Castiglione (Roma), Pollen \& Spores, 30, 329-356, 1988.

Follieri, M., Magri, D., and Sadori, L.: Pollen stratigraphical synthesis from Valle di Castiglione (Roma), Quatern. Int., 3-4, 81-84, 1989.

Follieri, M., Giardini, M., Magri, D., and Sadori, L.: Palynostratigraphy of the last glacial period in the volcanic region of central Italy, Quatern. Int., 47-48, 3-20, 1998.

Francke, A., Wagner, B., Just, J., Leicher, N., Gromig, R., Baumgarten, H., Vogel, H., Lacey, J. H., Sadori, L., Wonik, T., Leng, M. J., Zanchetta, G., Sulpizio, R., and Giaccio, B.: Sedimentological processes and environmental variability at Lake Ohrid (Macedonia, Albania) between $637 \mathrm{ka}$ and the present, Biogeosciences, 13, 1179-1196, doi:10.5194/bg-13-1179-2016, 2016.

Gasse, F., Vidal, L., Van Campo, E., Demory, F., Develle, A.-L., Tachikawa, K., Elias, A., Bard, E., Garcia, M., Sonzogni, C., and Thouveny, N.: Hydroclimatic changes in northern Levant over the past 400,000 years, Quaternary Sci. Rev., 111, 1-8, 2015.

Grimm, E. C.: CONISS: a fortran 77 program for stratigraphically constrained cluster analysis by the method of incremental sum of squares, Comput. Geosci., 13, 13-35, 1987.

Hoffmann, N., Reicherter, K., Grützner, C., Hürtgen, J., Rudersdorf, A., Viehberg, F., and Wessels, M.: Quaternary coastline evolution of Lake Ohrid (Macedonia/Albania), Cent. Eur. J. Geosci., 4, 94 110, 2012.

Imeri, A., Mullaj, A., Gjeta, E., Kalajnxhiu, A., Kupe, L., Shehu, J., and Dodona, E.: Preliminary results from the study of flora and vegetation of Ohrid lake, Natura Montenegrina, 9, 253-264, 2010.

Juggins, S.: C2 User guide. Software for ecological and palaeoecological data analysis and visualisation, University of Newcastle, Newcastle upon Tyne, UK, 69 pp., 2003.

Klaus, W.: Mediterranean pines and their history, Plant Syst. Evol., 162, 133-163, 1989.

Konijnendijk, T. Y. M., Ziegler, M., and Lourens, L. J.: On the timing and forcing mechanisms of late Pleistocene glacial terminations: insights from a new high-resolution benthic stable oxygen isotope record of the eastern Mediterranean, Quaternary Sci. Rev., 129, 308-320., 2005.

Koutsodendris, A., Müller, U. C., Pross, J., Brauer, A., Kotthoff, U., and Lotter, A. F.: Vegetation dynamics and climate variability during the Holsteinian interglacial based on a pollen record from Dethlingen (northern Germany), Quaternary Sci. Rev., 29, 3298 3307, 2010.

Laskar, J., Robutel, P., Joutel, F., Gastineau, M., Correia, A. C. M., and Levrard, B.: A long-term numerical solution for the insola- 
tion quantities of the Earth, Astron. Astrophys., 428, 261-285, 2004.

Leicher, N., Zanchetta, G., Sulpizio, R., Giaccio, B., Wagner, B., Nomade, S., Francke, A., and Del Carlo, P.: First tephrostratigraphic results of the DEEP site record from Lake Ohrid, Macedonia, Biogeosciences Discuss., 12, 15411-15460, doi:10.5194/bgd-12-15411-2015, 2015.

Leng, M. J., Baneschi, I., Zanchetta, G., Jex, C. N., Wagner, B., and Vogel, H.: Late Quaternary palaeoenvironmental reconstruction from Lakes Ohrid and Prespa (Macedonia/Albania border) using stable isotopes, Biogeosciences, 7, 3109-3122, doi:10.5194/bg7-3109-2010, 2010.

Lézine, A.-M., von Grafenstein, U., Andersen, N., Belmecheri, S., Bordon, A., Caron, B., Cazet, J.-P., Erlenkeuser, H., Fouache, E., Grenier, C., Huntsman-Mapila, P., Hureau-Mazaudier, D., Manelli, D., Mazaud, A., Robert, C. Sulpizio, R., Tiercelin, J.-J., Zanchetta, G., and Zeqollari, Z.: Lake Ohrid, Albania, provides an exceptional multi-proxy record of environmental changes during the last glacial-interglacial cycle, Palaeogeogr. Palaeocl., 287, 116-127, 2010.

Liepelt, S., Cheddadi, R., de Beaulieu, J.-L., Fady, B., Gömöry, D., Hussendörfer, E., Konnert, M., Litt, T., Longauer, R., TerhürneBerson, R., and Ziegenhagen, B.: Postglacial range expansion and its genetic imprints in Abies alba (Mill.) - A synthesis from palaeobotanic and genetic data, Rev. Palaeobot. Palyno., 153, 139-149, 2009.

Lindhorst, K., Vogel, H., Krastel, S., Wagner, B., Hilgers, A., Zander, A., Schwenk, T., Wessels, M., and Daut, G.: Stratigraphic analysis of lake level fluctuations in Lake Ohrid: an integration of high resolution hydro-acoustic data and sediment cores, Biogeosciences, 7, 3531-3548, doi:10.5194/bg-7-3531-2010, 2010.

Lindhorst, K., Krastel, S., Reicherter, K., Stipp, M., Wagner, B. and Schwenk, T.: Sedimentary and tectonic evolution of Lake Ohrid (Macedonia/Albania), Basin Res., 27, 84-101, 2015.

Lisiecki, L. E. and Raymo, M. E.: A Pliocene-Pleistocene stack of 57 globally distributed benthic $\delta^{18} \mathrm{O}$ records, Paleoceanography, 20, PA1003, doi:10.1029/2004PA001071, 2005.

Litt, T., Pickarski, N., Heumann, G., Stockhecke, M., and Tzedakis, P. C.: A 600,000 year long continental pollen record from Lake Van, eastern Anatolia (Turkey), Quaternary Sci. Rev., 104, 3041, 2014.

Magny, M., Combourieu-Nebout, N., de Beaulieu, J. L., BoutRoumazeilles, V., Colombaroli, D., Desprat, S., Francke, A., Joannin, S., Ortu, E., Peyron, O., Revel, M., Sadori, L., Siani, G., Sicre, M. A., Samartin, S., Simonneau, A., Tinner, W., Vannière, B., Wagner, B., Zanchetta, G., Anselmetti, F., Brugiapaglia, E., Chapron, E., Debret, M., Desmet, M., Didier, J., Essallami, L., Galop, D., Gilli, A., Haas, J. N., Kallel, N., Millet, L., Stock, A., Turon, J. L., and Wirth, S.: North-south palaeohydrological contrasts in the central Mediterranean during the Holocene: tentative synthesis and working hypotheses, Clim. Past, 9, 20432071, doi:10.5194/cp-9-2043-2013, 2013.

Magri, D., Vendramin, G. G., Comps, B., Dupanloup, I., Geburek, T., Gömöry, D., Latałowa, M., Litt, T., Paule, L., Roure, J. M., Tantau, I., Van Der Knaap, W. O., Petit, R. J., and De Beaulieu, J.-L.: A new scenario for the Quaternary history of European beech populations: Palaeobotanical evidence and genetic consequences, New Phytol., 171, 199-221, 2006.
Margari, V., Skinner, L. C., Tzedakis, P. C., Ganopolski, A., and Vautravers, M.: The nature of millennial-scale climate variability during the past two glacial periods, Nat. Geosci., 3, 127-131, 2010.

Matevski, V., Čarni, A., Avramovski, O., Juvan, N., Kostadinovski, M., Košir, P., Marinšek, A., Paušič, A., and Šilc, U.: Forest Vegetation of the Galičica Mountain Range in Macedonia, Založba ZRC, Ljubljana, 2011.

Médail, F. and Diadema, K.: Glacial refugia influence plant diversity patterns in the Mediterranean Basin, J. Biogeogr., 36, 13331345, 2009.

Milner, A. M., Collier, R. E. L., Roucoux, K. H., Muller, U. C., Pross, J., Kalaitzidis, S., Christanis, K., and Tzedakis, P. C.: Enhanced seasonality of precipitation in the Mediterranean during the early part of the Last Interglacial, Geology, 40, 919-922, 2012.

Moreno, A., Svensson, A., Brooks, S. J., Connor, S., Engels, S., Fletcher, W., Genty, D., Heiri, O., Labuhn, I., Persoiu, A., Peyron, O., Sadori, L., Valero-Garces, B., Wulf, S., Zanchetta, G., and data contributors: A compilation of Western European terrestrial records 60-8 ka BP: towards an understanding of latitudinal climatic gradients, Quaternary Sci. Rev., 106, 167-185, 2015.

Okuda, M., Yasuda, Y., and Setoguchi, T.: Middle to Late Pleistocene vegetation history and climatic changes at Lake Kopais, Southeast Greece, Boreas, 30, 73-82, 2001.

Panagiotopoulos, K.: Late Quaternary ecosystem and climate interactions in SW Balkans inferred from Lake Prespa sediments, PhD thesis, Universität zu Köln, Germany, 2013.

Panagiotopoulos, K., Aufgebauer, A., Schäbitz, F., and Wagner, B.: Vegetation and climate history of the Lake Prespa region since the Lateglacial, Quatern. Int., 293, 157-169, 2013.

Panagiotopoulos, K., Böhm, A., Leng, M. J., Wagner, B., and Schäbitz, F.: Climate variability over the last $92 \mathrm{ka}$ in SW Balkans from analysis of sediments from Lake Prespa, Clim. Past, 10, 643-660, doi:10.5194/cp-10-643-2014, 2014.

Petit, R. J., Hampe, A., and Cheddadi, R.: Climate changes and tree phylogeography in the Mediterranean, Taxon, 54, 877-885, 2005.

Popovska, C. and Bonacci, O.: Basic data on the hydrology of Lakes Ohrid and Prespa, Hydrol. Process, 21, 658-664, 2007.

Pross, J., Koutsodendris, A., Christanis, K., Fischer, T., Fletcher, W. J., Hardiman, M., kalaitzidis, S., Knipping, M., Kotthoff, U., Milner, A. M., Müller, U. C., Schmiedl, G., Siavalas, G., Tzedakis, P. C., and Wulf, S.: The 1.35-Ma-long terrestrial climate archive of Tenaghi Philippon, northeastern Greece: Evolution, exploration and perspectives for future research, Newsl. Stratigr., 48, 253-276, 2015.

Railsback, L. B., Gibbard, P. L., Head, M. J., Voarintsoa, N. R. G.. and Toucanne, S: An optimized scheme of lettered marine isotope substages for the last 1.0 million years, and the climatostratigraphic nature of isotope stages and substages, Quaternary Sci. Rev., 111, 94-106, 2015.

Reille, M.: Pollen et spores d'Europe et d'Afrique du Nord, Laboratoire de botanique historique et palynology, Marseille, France, 520 pp., 1992.

Reille, M.: Pollen et spores d'Europe et d'Afrique du Nord, Supplement I, Laboratoire de botanique historique et palynology, Marseille, France, 327 pp., 1995. 
Reille, M.: Pollen et spores d'Europe et d'Afrique du Nord. Laboratoire de botanique historique et palynologie, Supplement II, Marseille, France, 521 pp., 1998.

Reille, M., de Beaulieu, J. L., Svobodova, H., Andrieu-Ponel, V., and Goeury, C.: Pollen stratigraphy of the five last climatic cycles in a long continental sequence from Velay (Massif Central, France), J. Quaternary Sci., 15, 665-685, 2000.

Roucoux, K. H., Tzedakis, P. C., Frogley, M. R., Lawson, I. T., and Preece, R. C.: Vegetation history of the marine isotope stage 7 interglacial complex at Ioannina, NW Greece, Quaternary Sci. Rev., 27, 1378-1395, 2008.

Roucoux, K. H., Tzedakis, P. C., Lawson, I. T., and Margari, V.: Vegetation history of the penultimate glacial period (Marine Isotope Stage 6) at Ioannina, north-west Greece, J. Quaternary Sci., 26, 616-626, 2011.

Sánchez Goñi, M. F., Eynaud, F., Turon, J. L., and Shackleton, N. J.: High resolution palynological record off the Iberian margin: Direct land-sea correlation for the Last Interglacial complex, Earth Planet. Sc. Lett., 171, 123-137, 1999.

Smit, A.: A scanning electron microscopical study of the pollen morphology in the genus Quercus, Acta Bot. Neerl., 22, 655$665,1973$.

Stockmarr, J.: Tablets with spores used in absolute pollen analysis, Pollen \& Spores, 13, 615-621, 1971.

Sulpizio, R., Zanchetta, G., D’Orazio, M., Vogel, H., and Wagner, B.: Tephrostratigraphy and tephrochronology of lakes Ohrid and Prespa, Balkans, Biogeosciences, 7, 3273-3288, doi:10.5194/bg7-3273-2010, 2010.

Tzedakis, P. C.: Hierarchical biostratigraphical classification of long pollen sequences, J. Quaternary Sci., 9, 257-259, 1994a.

Tzedakis, P. C.: Vegetation change through glacial/interglacial cycles: a long pollen sequence perspective, Philos. T. R. Soc. Lond. B., 345, 403-432, 1994b.

Tzedakis P. C.: Seven ambiguities in the Mediterranean palaeoenvironmental narrative, Quaternary. Sci. Rev., 26, 2042-2066, 2007.

Tzedakis, P. C.: Museums and cradles of Mediterranean biodiversity, J. Biogeogr., 36, 1033-1034, 2009.

Tzedakis, P. C., Andrieu, V., de Beaulieu, J.-L., Crowhurst, S., Follieri, M., Hooghiemstra, H., Magri, D., Reille, M., Sadori, L., Shackleton, N. J., and Wijmstra, T. A.: Comparison of terrestrial and marine records of changing climate of the last 500,000 years, Earth Planet. Sc. Lett., 150, 171-176, 1997.

Tzedakis, P. C., Andrieu, V., Birks, H. J. B., de Beaulieu, J.-L., Crowhurst, S., Follieri, M., Hooghiemstra, H., Magri, D., Reille, M., Sadori, L., Shackleton, N. J., and Wijmstra, T. A.: Establishing a terrestrial chronological framework as a basis for biostratigraphical comparisons, Quaternary Sci. Rev., 20, 1583-1592, 2001.

Tzedakis, P. C., Lawson, I. T., Frogley, M. R., Hewitt, G. M., and Preece, R. C.: Buffered Tree Population Changes in a Quaternary Refugium: Evolutionary Implications, Science, 297, 2044-2047, 2002.

Tzedakis, P. C., Frogley, M. R., Lawson, I. T., Preece, R. C., Cacho, I., and de Abreu, L.: Ecological thresholds and patterns of millennial-scale climate variability: The response of vegetation in Greece during the last glacial period, Geology 32, 109-112, 2004a.
Tzedakis, P. C., Roucoux, K. H., de Abreu, L., and Shackleton, N. J.: The duration of forest stages in southern Europe and interglacial climate variability, Science, 306, 2231-2235, $2004 \mathrm{~b}$.

Tzedakis, P. C., Hooghiemstra, H., and Pälike, H.: The last 1.35 million years at Tenaghi Philippon: revised chronostratigraphy and long-term vegetation trends, Quaternary Sci. Rev., 25, 34163430, 2006.

Tzedakis, P. C., Raynaud, D., McManus, J. F., Berger, A., Brovkin, V., and Kiefer, T.: Interglacial diversity, Nat. Geosci., 2, 751-755, 2009.

Tzedakis, P. C., Emerson, B. C., and Hewitt, G. M.: Cryptic or mystic? Glacial tree refugia in northern Europe, Trends Ecol. Evol., 28, 696-704, 2013.

Wagner, B., Lotter, A. F., Nowaczyk, N., Reed, J. M., Schwalb, A., Sulpizio, R., Valsecchi, V., Wessels, M., and Zanchetta, G.: A 40,000-year record of environmental change from ancient Lake Ohrid (Albania and Macedonia), J. Paleolimnol., 41, 407-430, 2009.

Wagner, B., Vogel, H., Zanchetta, G., and Sulpizio, R.: Environmental change within the Balkan region during the past ca. $50 \mathrm{ka}$ recorded in the sediments from lakes Prespa and Ohrid, Biogeosciences, 7, 3187-3198, doi:10.5194/bg-7-3187-2010, 2010.

Wagner, B., Wilke, T., Krastel, S., Zanchetta, G., Sulpizio, R., Reicherter, K., Leng, M. J., Grazhdani, A., Trajanovski, S., Francke, A., Lindhorst, K., Levkov, Z., Cvetkoska, A., Reed, J. M., Zhang, X., Lacey, J. H., Wonik, T., Baumgarten, H., and Vogel, H.: The SCOPSCO drilling project recovers more than 1.2 million years of history from Lake Ohrid, Sci. Dril., 17, 19-29, 2014.

Wang, P., Tian, J., and Lourens, L.: Obscuring of long eccentricity cyclicity in Pleistocene oceanic carbon isotope records, Earth Planet. Sc. Lett., 290, 319-330, 2010.

Watzin, M. C., Puka, V., and Naumoski, T. B. (Eds.): Lake Ohrid and its Watershed, State of the Environment Report, Lake Ohrid conservation project, Tirana, Albania and Ohrid, Macedonia, 134 pp., 2002.

Wijmstra, T. A.: Palynology of the first $30 \mathrm{~m}$ of a $120 \mathrm{~m}$ deep section in northern Greece, Acta Bot. Neerl., 18, 511-527, 1969.

Wijmstra, T. A. and Smit, A.: Palynology of the middle part (30$78 \mathrm{~m}$ ) of a $120 \mathrm{~m}$ deep section in northern Greece (Macedonia), Acta Bot. Neerl., 25, 297-312, 1976.

Zagwijn, W. H.: The beginning of the Ice Age in Europe and its major subdivisions, Quaternary Sci. Rev., 11, 583-591, 1992.

Zanchetta, G., Regattieri, E., Giaccio, B., Wagner, B., Sulpizio, R., Francke, A., Vogel, L. H., Sadori, L., Masi, A., Sinopoli, G., Lacey, J. H., Leng, M. L., and Leicher, N.: Aligning MIS5 proxy records from Lake Ohrid (FYROM) with independently dated Mediterranean archives: implications for core chronology, Biogeosciences Discuss., 12, 16979-17007, doi:10.5194/bgd12-16979-2015, 2015. 